\title{
REFERRING AND THE CONTEXT OF SITUATION IN VIEW OF THE HUMAN LINGUISTICS APPROACH
}

\section{Introduction}

Based on false philosophical assumptions, language has so far been considered as an entity, a thing which exists on its own and has characteristics of a living being. Language has been said to evolve and languages have been classified as alive or dead. Language has been considered as something you can acquire.

The turn of the century witnessed the rise of the first scientifically justified theory of linguistics, the Human Linguistics (Yngve 1996), which does not treat language as an entity of its own, independently of people, but rather basis its research on real-world evidence and shifts the focus of its enquiry to the individual processing the sounds or ink on paper in the relevant context of situation.

\section{Survey of traditional investigation of language}

The treatment of language as an independent entity, separate from the individual, can be traced back to the ancient Greek philosophers such as Plato and prominent linguists such as Saussure and his structural approach to linguistics where he proposes that language be treated in terms of a relation of word to thing or the world.

The second half of the $20^{\text {th }}$ century fathered the rise of the functionalist approach to studying language (Halliday 1985, Haliday \& Hasan 1976, Yule 1996, de Beaugrande \& Dressler 1981) which, as opposed to the structuralist approach, brought forward the importance of context over sentence structure for the meaning of the utterance. The focus of linguistic enquiry was shifted from word and sentence to larger stretches of text. The term discourse analysis was introduced to denote linguistic research at the level of text and context.

Discourse linguistics together with the structuralist approach paved the way for the late $20^{\text {th }}$ century communicative approach to linguistics (Schiffrin 1994, Cook 2003,) which based its theoretical background on both leading approaches to language study: the structuralist and the functionalist approach. It was the understanding of the communicative approach that both the functionalist and structuralist approaches contribute equally to the understanding of language and are mutually dependent on each other (Cook 2003). Utterance rather than sentence became the key word in discussions of language and its communicative functions.

Individual instances of using language in single acts of uttering called énonces ( $T$. Todorov 1970) became the focus of linguistic studies underlying the need for language analysis from the individual not systemic perspective. 
This view was put forward already in the 50s and the 60s of the previous century. Austin discusses language in terms of similarities in certain social communicative acts, where the subject of human communicative activities is approached from the viewpoint of the Speech Act Theory. According to his 1962 book 'How to Do Things with Words' ( $1^{\text {st }}$ ed. 1955), Austin's philosophy was that every utterance one makes is really an act. We either describe an event (locutionary, such as 'it's raining'), use verbs to make performing an act explicit (illocutionary, such as 'I apologize'), or to produce an effect on those around us (perlocutionary; performatives, such as 'we, the jury, find the defendant guilty...').

\section{Human Linguistics - a theory of scientific linguistics}

A scientific approach to studying language as proposed by Victor H. Yngve's Human Linguistics (HL; 1996) represents a means of focusing linguistic research on the communicative structure of people rather than language structures or utterances, as has been the case in the past. It is the communicative ability of people which grows and develops and can be acquired by observing and by taking an active part in communicative situations. The composing elements of language such as, in traditional terms, syllables, words or sentences, do not evolve or undergo any change independently of people. It is people who change and interpret the sound waves or ink on paper in the relevant environment.

In the theory of HL, acts of communicating are first analyzed in terms of the physical reality - the real-world objects involved - which is the assemblage ${ }^{1}$. The analysis of the communicative situation involves discussion in terms of HL defined linkages ${ }^{2}$. This requires that we use the HL formalization to represent linkages and their composing parts in the theory. Square brackets are used to denote systems, which are linkages, linkage participants ${ }^{3}$, role parts ${ }^{4}$ and props $^{5}$, while angle brackets denote properties of systems, various tasks and procedures.

Formalizing acts of communicating as linkages, featuring linkage participants, role parts, props, and carrying out relevant task procedures offers an insight into the complexity and multiplicity of human communicating activities and represents a

1 The term assemblage is used to denote a "group of people together with their linguistically relevant surroundings involved in a particular communicative behavior." (Yngve 1996:86)

2 In HL theory, a linkage is defined as "a representation in linguistic theory of an assemblage that includes just those properties that are required to account for the communicative behavior associated with the assemblage." (Yngve 1996:126)

3 A linkage participant is in HL theory defined as 'a representation of a person that includes just those properties that are required to account for that person's communicative behavior in a particular assemblage.' (Yngve 1996:125)

4 A role part is defined in HL as 'a representation of the functional part or role that a person plays in a particular assemblage.'(Yngve 1996:193)

5 'A prop is a representation in linguistic theory of a real-world object, instrument, or device in an assemblage that includes just those properties that are required for its communicative relevance in the assemblage.' (Yngve 1996:129) 
means of an integrated analysis of the multiple factors active in an instance of human communicating.

\section{Problems of the traditional notion of reference}

In general, human communicating can in traditional terms be viewed as the use of words to refer to things in the external reality or imagined external reality, words being items that name the things in the external or imagined external reality. In the past, the subject of names and referring has been addressed by linguists, as well as prominent authors of philosophical, fictional and scientific texts, such as Socrates, Shakespeare or Galileo. They have all doubted the traditional notion of treating a word as an independent and powerful entity which has or carries meaning, refers to things in the real world, and causes responses in humans.

\section{Socrates on names}

In Plato's Collected Dialogues (Hamilton, E. and Cairns, H., eds. 1961), we find an interesting discussion between Socrates and one of his students, Cratilus, debating the meaning of words, primitive or first nouns which are viewed as representations of things. A doubt introduced in this dialogue is the one of the lack of real-world scientific evidence that words as such possess the power they are being assigned by philosophers. Socrates points out that the nature of words is such that it demands a social convention and previous knowledge related to the intended meaning of the word in order to be used successfully and effectively (verse 433 (p. 467). Words as such bear no likeness to the objects they are a representation of. Letters as composing parts of the word are not real-world objects and as such their clusters cannot form real-world entities (verse 434, p. 468). It is not words that have power, it is the individual that endows words with power. On their own, words are just sound waves or ink on paper. On the other hand, by means of convention, one can choose to call black white and white black, as long as the parties involved are agreed on it.

\section{Shakespeare on names}

"What's in a name? That which we call a rose by any other name would smell as sweet." (W. Shakespeare)

This famous quote by Shakespeare is the author's expression of doubt concerning the powerful use of names. The two names, Montague and Capulet, do not bear any negative meaning in themselves. It is the people as real-world objects who assign negative characteristics to them in the play.

\section{Galileo on names}

Galileo, as the father of modern science, was an observer of the world around him. His contribution to scientific research is represented by the idea that there is a clear distinction between the humanities and science, between the sensations and the external phenomena. He was concerned with divorcing the hard science from the idea that words have the kind of power with which they are endowed by philosophers 
(separation of primary from secondary qualities; Drake, 1980:71). He expressed his basic concern in the form of the witty remarks made in reference to using words as names which function as representations of real-world objects:

'If their opinions and their voices have the power to call into existence the things they name, then I beg them to do me a favour of naming a lot of old hardware I have about my house 'gold'. (D\&O 253)' (in Drake, 1980:71,)

\section{Handling referring in $\mathrm{HL}$ - example of the game of 'tag'}

The subject of reference in traditional terms, or referring behavior in human linguistic terms, has been discussed in Yngve (1996, chapter 21) and the distinction between the traditional and the HL notions has been made (cf. also Burazer 2004). In tradition, it is the words and propositions that refer to real-world objects, it is the words that point to things in the environment. In $\mathrm{HL}$, it is people who refer, not words (Burazer, 2004, chapter 8) and we speak of referring behavior.

\section{The context of situation - the Domain of control}

When speaking of referring, tradition inevitably brings into the discussion the relevant context on which the use of words depends. In HL, this dependence on the context is addressed from the point of view of the human being and the relevant procedures in them that become active, stand ready or nearly ready to be triggered, which together constitute the participant's domain of control.

The game of tag is an example of a simple communicative activity involving a number of players where one of the players is 'it' and the others are 'not it'. In the theory of HL we first define the game in terms of the physical reality - the real-world objects involved in it, which is the assemblage consisting of the playground and the children on the playground who are involved in the game of tag.

We set up a linkage [playground] with a role part [tag player] for each of the children in the assemblage on the playground (note the use of square brackets for systems). The playground activities are represented in the theory as linkage tasks and subtasks, formalized by the use of angle brackets as in (1).

\section{(1) Linkage [playground $]=$ participants $[\mathrm{Al}]+[$ Butch $]+[$ Carl $]+[$ Dan $]+[$ Eric $]$}

\section{Referring behavior and the game of tag}

The game of tag is a relatively simple communicative activity, particularly in the linguistic sense, with no or very little verbal communication involved. The only verbal activity in the game, which is optional, are the sounds of 'tag' and/or 'you're it' uttered by the player who is 'it' after having touched/tagged one of the players who is not 'it'. Yet the activities triggered in the participants by a simple touch (and sometimes an utterance) are manifold and complex.

Being a participant in the tag linkage, a number of parallel participant tasks are selected and triggered in the players in order for the linkage task of <play the game of tag $>$ to execute successfully. The main task of the players who are not 'it' is to <avoid 
the player who is 'it'>. The players who are not 'it' also have other tasks active in parallel, such as monitoring. This involves constantly paying attention to who is 'it' at any given moment.

The conditional role-part property of being 'it' is a dynamically changing one, frequently alternating its value throughout the game. The parallel task of monitoring who is 'it' needs to be active at all times. The participant who performs the activity of tagging is referring to the other participant's expectation procedures which are subsequently triggered. That is why we speak of referring behavior rather than just reference. First, a certain set of tasks is executed in one participant; their execution then results in triggering a set of tasks in another participant. The two sets of tasks in the two participants have to be compatible in the sense that they relate to the same domain of control (the tradition calls this the context of situation). The act of tagging triggers the relevant set of expectation procedures in the tagged participant on condition that the relevant set of expectation procedures is ready to be triggered and the related tasks ready to be activated, in which case the participant's behavior would change accordingly.

By referring to a participant's domain of control and relevant expectation procedures, the communicating individual is assuming and at the same time validating his assumption that the other communicating individual has a corresponding domain of control with similar concepts. In the process of communicating, individuals are constantly monitoring for validation of each other's behavior (the other participant's nods, responses and other expressions of agreement and understanding) which gives them reassurance that similar concepts are being accessed in the plexes ${ }^{6}$ of their partners in communicating, forming a similar domain of control. Therefore human communicating is based on expectation procedures in participants involved in a relevant communicative situation which are that the other participants have the concepts forming the relevant domain of control.

\section{How do we account for successful referring?}

Although people share some common ground, they come from different backgrounds, which brings us to the question of how it is at all possible for any human communication to be successful, since our personal histories differ and thus contribute different input into the context of situation. Other linguists have expressed this fear for the process of making linguistics scientific. Bloomfield, for instance, feared that 'the occurrence of a speech [...] depend[s] upon the entire life-history of the speaker and of the hearer' (Bloomfield, in Yngve 1996: p.170). But the HL theory eliminates these fears because it finds that communicative behavior is lawful, which means that it is possible to discover the laws related to any given piece of communicative behavior, and thus achieve a scientific understanding of it (Yngve, 1996:p.171). People expect

\footnotetext{
${ }^{6}$ In HL, plex is a representation of the structure of a communicating individual as a long list of procedures all interrelated by categorial and conditional properties in a complex dynamic causal network (Yngve 1996:171).
} 
conformity to norms and easily overlook deviations or actually hear them according to their expectations (cf. Burazer 2004, SLE, Norway), otherwise human communication would in most cases result in failure.

Success of referring behavior is conditioned by the domain of control in the participants in a particular linkage. This does not imply that participants have the same life history, which is of course impossible, but we are rather counting here on the principle of equivalent componential histories relating to the particular domain of control (Yngve 1996:169).

People learn by observing and discovering patterns in human behavior. On the basis of the observed behavior in the tag linkage, for instance, the basic principle of the game of tag can in HL be formalized as (2):

$[\mathrm{X}]<\mathrm{i}>\mathrm{x}[\mathrm{Y}]<-\mathrm{i}>\mathrm{x}[\mathrm{X}]<\operatorname{tag}>(\mathrm{Y})::$

$[\mathrm{X}]<-\mathrm{i}>\mathrm{x}[\mathrm{Y}]<\mathrm{it}>$

The above is a formalization of the basic procedural property of the tag linkage. It represents the participants' activities in the process of tagging, which is a repetitive pattern of communicative behavior in the tag linkage. The participants $\mathrm{X}$ and $\mathrm{Y}$ have the property of being it/-it at a certain value at a certain point in the game. The participant who is 'it' touches the other participant, who is '-it', which sets the participant X's property of being 'it' to change to '-it', and the participant Y's property of '-it' to 'it'.

The discovery of patterns of communicative activities can also be sensed behind Austin's and later Searle's approach to analyzing human communication in terms of speech acts. Speech acts are a theoretical representation of patterns of human behavior underlying interpersonal communicative activities.

\section{The Speech Act Theory approach}

In line with the Speech Act Theory, the activity of tagging can be interpreted as the player performing a perlocutionary (performative) speech act: 'you're it' really means 'I tagged you'. This behavior is rule governed, since there are certain rules of the game that the players observe. Searle's hypothesis was that speaking a language is a matter of performing speech acts according to systems of constitutive rules (1969:38).

Prior to stating this hypothesis he compares human behavior in games such as football, baseball and chess (1969:36; this analogy has been used prior to Searle by Saussure and Witgenstein) to human behavior in certain social situations. Violating the rules of a game results in negative attitude towards the particular player or team. Generally, in social behavior such violations or adherence to the rules (of etiquette) would represent the basis for appraisal of behavior, such as 'he was rude', 'he was immoral', 'he was polite', which Searle tentatively poses as evidence for existence of rule governed human behavior.

We can claim with some certainty that there exists evidence from everyday examples that human behavior is 'rule governed'7. These 'rules' are forms of socially

\footnotetext{
${ }^{7}$ Note the use of inverted commas to mark that this expression in itself represents a domain confusion and as such is not a part of terminology used in Human linguistics.
} 
accepted behavior. Apart from the criminal behavior defined by the law, people are not legally bound to behave in a certain way, but society as such dictates certain ways of accepted behavior, and consequently condemns deviations from these ways as unacceptable. It is human nature to have the need to belong and be accepted by the society, therefore we can note in human behavior conformity to norms.

The rules of socially accepted behavior undergo considerable changes through time. Numerous examples from everyday situations support this statement.

In the past, before the existence of modern telecommunication systems, such as telegraphs, telephones and the electronic media, people used to communicate indirectly through messengers or through the postal service. So, for instance, arranging to meet someone took quite a while if one wanted to come announced, in addition to observing certain norms of social behavior. Then, with the invention of the telegraph, getting a message through to someone became considerably easier and quicker, and even more so with the invention of the telephone. Showing up at someone's doorstep all of a sudden became incredibly rude - at least in my experience. The social norm became 'You should call first.' If one did happen to show up at someone's doorstep, one would have noticed a change in communication from 'I'm so glad you're home' to suddenly apologizing 'Sorry, I know I should have called first.'

Nowadays, in the time of mobile telephones and electronic mail communication, it might be unimaginable to just show up at someone's doorstep, even if you did just happen to pass their house. The rules of social behavior dictate that it is polite and expected of you to call first, even if you're standing right in front of the person's doorstep. The availability of modern means of communication has changed people's perception of what can be expected of the other person in terms of making interpersonal communication easier, so a certain level of predictability of human behavior is expected.

Similarly, expectations have changed in terms of decoding the meaning of sounds such as music heard in the middle of the street or in a classroom situation, or a person 'talking to themselves' in a coffee shop. Some time ago, these instances would have probably been understood as some sort of deviations from the social norms of behavior. Nowadays, the first expectation when music is heard seems to be that it must be someone's mobile telephone. And if one hears someone walking behind them and talking loud, one expects they are talking to someone on the phone rather than addressing them or talking to themselves.

Validation and appraisal of our past behavior results in forming expectation procedures in an individual's plex which are then triggered in a particular situation, accessing appropriate related concepts and further triggering appropriate task procedures, in accordance with the individual's social and cultural experience.

\section{Conclusion}

The words reference and referring constitute a part of terminology in many different fields of research and we, the readers/listeners, manage to adjust their specific meanings in accordance with the field of research in question. Definitions from 
philosophy imply that it is words that refer to or point out objects and other worldly phenomena. But in human linguistics it is not words but people who refer or point to something.

In human linguistics, participants do not refer to elements or words in the text. It is concepts in the hearer's or reader's domain of control that are accessed. They are concepts of items in the external reality or in the imagined external reality or abstract concepts. A certain given communicative behavior may trigger access to different concepts at different times depending on the domain of control.

But in human linguistics, referring behavior is concerned with the triggering of procedures in dependence on the context rather than with people using words (Yngve 1996:277), as in traditional linguistics. In human linguistics, communicating individuals are the participants in the process of communicating, and their linguistic, social, and emotional properties are involved in their understanding of referring behavior. Traditional analysis of grammatical structures and lexis reveals the surface layer of the message. It does not, however, explain the phenomena behind successful communication in cases such as two friends using unfinished sentences and cue words, or in cases where the message carries double meaning, yet the receiver extracts the correct one, suitable to the particular context of situation.

In order to be able to account for how people communicate, a much wider framework is needed-one that reaches beyond surface grammatical structures, or even the context of situation-one that takes into account all factual elements playing a role in successfully communicating. This requires that we move from the logical to the physical domain of investigation, and Human Linguistics is the theory equipped with the proper means to do so. 


\section{Bibliography}

Austin. J.L. 1962. 'How to Do Things with Words'. 2nd ed. (first 1955) Cambridge: Harvard UP.

BEAUgrande, Robert-Alain de, and Dressler, Wolfgang. 1981. Introduction to text linguistics. London; New York: Longman.

Burazer, Lara. 2004. 'Handling Context Dependence in a Human Linguistic Framework'. Paper at the $37^{\text {th }}$ annual SLE meeting, 'Effects of mobility on language'. Kristiansand, Norway, 27th-31 ${ }^{\text {st }}$ July.

BuraZER, Lara. 2004. 'Reconstituting Notions of Reference'. In Hard-Science Linguistics, Yngve and Wasik, eds. Continuum: London, New York.

Cook, Guy. 2003. 'Applied Linguistics'. Oxford: Oxford University Press.

DRAKE, Stillman. 1961. 'GALILEO'. Past masters series, Hill and Wang, New York, A division of Farrar, Straus and Giroux, 1980:71

HALIDAY, M.A.K. \& Hasan, Raqaiya. 1976. 'Cohesion in English'. London: Longman.

HALLIDAY, M.A.K. 1985. 'An introduction to functional grammar'. London ; Baltimore, Md., USA : Edward Arnold.

Hamilton, E. and Cairns, H., eds. 1961. 'The Collected Dialogues of Plato including the letters'. Bollingen Series LXXI, Pantheon Books. Bollingen Foundation, New York, N.Y.

SAussure, Ferdinand de. 1974. 'Course in General Linguistics' (trans. Wade Baskin). London: Fontana/Collins. SCHIFFRIN, Deborah. 1994. 'Approaches to discourse'. Oxford: Blackwell.

SEARLE, John R. 1969. 'Speech Acts - An Essay in the Philosophy of Language'. CUP: London, New York.

SHAKESPEARE, William. 1987. 'Romeo and Juliet'. UK: OUP.

ToDorov, Tzvetan. 1970. 'Introduction à la littérature fantastique', Paris : Éditions du Seuil.

YNGVE, Victor H. 1996. 'From Grammar to Science- New Foundations for General Linguistics'. John Benjamins Publishing Company: Amsterdam - Philadelphia.

Yule, George. 1996. 'Pragmatics'. Oxford: Oxford University Press. 


\section{Povzetek \\ POJMOVANJE REFERENCE (NANAŠANJA) IN SITUACIJSKEGA KONTEKSTA \\ S STALIŠČA JEZIKOSLOVJA ČLOVEKA}

Referenca oz. nanašanje je pojem, ki se pogosto pojavlja tako $\mathrm{v}$ filozofskem kot $\mathrm{v}$ jezikoslovnem diskurzu. V preteklosti je bila referenca definirana kot odnos med besedo ali izrazom in predmetom $v$ resničnosti oz. med besedo in pojmom $v$ abstraktni resničnosti. Kljub nekaterim porajajočim se dvomom $v$ to filozofsko osnovo jezikoslovne znanosti, je pojmovanje, da je jezik predmet obravnave v jezikoslovju, ostalo zakoreninjeno. Victor H. Yngve s svojo teorijo jezikoslovja človeka (Human Linguistics, tudi HL) predstavlja korak izven okvirov jezikoslovja jezika, kjer je predmet znanstvene obravnave s stališča trdih znanosti neotipljiv. Za predmet znanstvene obravnave postavlja človeka in njegove odzive v različnih komunikacijskih situacijah.

Obravnava reference $s$ stališča jezikoslovja človeka na primeru preproste otroške igre lovljenja omogoča vpogled v zapleteno mrežo človeškega razumevanja v situacijskem kontekstu. Rezultati obravnave kažejo, da je človeško medsebojno komuniciranje, v vsej svoji zapletenosti in sočasnemu vplivu številnih dejavnikov, moč znanstveno formalizirati v okviru orodij, ki jih ponuja HL. Kljub nesporni raznolikosti izkušenj, si ljudje delimo številne družbeno sprejete vedenjske vzorce, ki predstavljajo skupni imenovalec človeškega delovanja in zagotavljajo uspešnost komunikacije. 